Check for updates

Cite this: RSC Adv., 2017, 7, 43141

\title{
Chitosan promotes ROS-mediated apoptosis and S phase cell cycle arrest in triple-negative breast cancer cells: evidence for intercalative interaction with genomic DNA
}

\author{
Fahimeh Salehi, (DD ${ }^{a}$ Hossein Behboudi, (DD ${ }^{a}$ Gholamreza Kavoosi ${ }^{b}$ \\ and Sussan K. Ardestani ${ }^{\star a}$
}

Chitosan (CS) is a semi-synthetic bio-based polysaccharide with promising biological and antitumor properties. However, its possible underlying anticancer mechanisms and molecular interactions have remained largely unknown. Herein, we have shown that CS exerts an inhibitory effect on the proliferation of MDA-MB-231, MCF-7 and T47D breast cancer cells in a dose and time-dependent manner while being non-toxic to fibroblast L929 normal cells. Exposure of MDA-MB-231 cells to CS led to depolarization of the mitochondrial membrane, increase in ROS, DNA oxidation, and $\mathrm{S}$ phase cell cycle arrest. Furthermore, EB/AO staining, Annexin-PI staining, TUNEL assay, and altered expression of caspase 3 in MDA-MB-231 cells all indicated that cancer cells progressively became apoptotic upon CS exposure. S phase arrest in MDA-MB-231 cells suggests possible CS-DNA interaction. UV-visible spectroscopy confirmed CS interaction with DNA, and competitive displacement fluorescence assay revealed a binding constant of $7.6 \times 10^{5} \mathrm{M}^{-1}$ for CS. In addition, its binding modes with DNA were established by $C D$ analysis. These results clearly indicate that along with being a safe biopolymer to normal cells, CS can be considered as an effectual anticancer agent.

Received 18th June 2017
Accepted 14th August 201

DOI: $10.1039 / c 7 r a 06793 c$

rsc.li/rsc-advances

\section{Introduction}

Recent advancements in breast cancer treatment using chemotherapy, radiotherapy, and surgery have extended the life expectancy of patients considerably. ${ }^{1-3}$ However, serious side effects, low specificity and drug resistance of anticancer drugs have inspired scientists to search for more effective and harmless medication. ${ }^{4}$

The tightly regulated apoptosis extrinsic pathway that is triggered via death receptors present on the surface of the cell, and the mitochondrial-dependent intrinsic pathway are the key factors in maintaining cellular homeostasis. ${ }^{5}$ Under normal circumstances, Reactive Oxygen Species (ROS) and the cellular antioxidant system exist in balance. Disturbing this balance and collective generation of ROS causes oxidative stress. Findings show that ROS not only functions as a regulator of subcellular events but also is able to induce cell death through the apoptotic pathway. High concentration of ROS causes damage to DNA, proteins and lipids, which can lead to cell death. Furthermore, increasing pieces of evidence suggest that oxidative stress induces mitochondrial dysfunction. ${ }^{6}$

${ }^{a}$ Institute of Biochemistry and Biophysics, Department of Biochemistry, University of Tehran, Tehran, Iran. E-mail: ardestany@ut.ac.ir

${ }^{b}$ Institute of Biotechnology, Shiraz University, Shiraz, Iran
Drugs with the ability of inhibiting DNA synthesis are among the best choices to treat fast proliferating cancer cells. ${ }^{7}$ DNAsmall molecules interaction leads to significant modification in DNA structure and may result in hindered or suppressed function of nucleic acids in physiological processes. ${ }^{8-10}$ Therefore, studying the interaction of potential anticancer agents with DNA and understanding their modes of action may help significantly to design new drugs for clinical use. ${ }^{11,12}$ DNA-drug interactions occur via whether covalent or noncovalent (electrostatic interactions, grooves binding, intercalation) binding and small differences in molecular structure may greatly affect the binding modes and as a result the stability of DNA-molecule complexes. ${ }^{13}$ Negatively charged DNA phosphate backbone interacts with the positively charged ends of small molecules via electrostatic binding, whereas major and minor groove binding involve hydrogen bonding or van der Waals interaction with nucleic acid bases. On the other hand, intercalation occurs when small molecules intercalate within the nucleic acid base pairs. ${ }^{12,14}$ Berenil, bleomycin and distamycin A (groove binding agents), tamoxifen, doxorubicin, daunomycin, quinolones, and quinoxalines (DNA intercalative agents) ${ }^{12}$ are some of the successful therapeutic DNA-interacting agents.

Natural products have played a pivotal rule in guiding researchers to develop efficient anticancer agents. ${ }^{15}$ Many polysaccharides extracted from natural sources have been found to 
possess a variety of biological activities and can be classified into two groups based on their sources, ${ }^{\mathbf{1 6}}$ natural and semi-synthetic polysaccharides, which are produced by chemical or enzymatic modifications of the parent macromolecules. Numerous studies have reported that natural polysaccharides can inhibit tumor cells proliferation either by directly inducing apoptosis or by triggering immunopotentiation activity in combination with chemotherapy. ${ }^{\mathbf{1 7}}$ Chitosan (CS), a semi-synthetically bio-based polymer, a deacetylation derivative of chitin (a polysaccharide presents in the exoskeleton of crustaceans, fungi, and insects) under alkaline condition, is a linear copolymer comprised of randomly distributed $\beta$ - $(1 \rightarrow 4)$-linked 2-amino-2-deoxy-D-glucopyranose and 2-amino-2-deoxy-D-glucopyranose units. ${ }^{\mathbf{1 8 - 2 0}}$ Due to favorable properties such as biocompatibility, biodegradability in presence of chitinase, chitosanase, lysozyme, and nontoxicity, this cationic polysaccharide has been widely studied and developed for a variety of biomedical and pharmaceutical applications, including fungistatic and antibacterial, antitumor, anti-inflammatory, antioxidant, immunoadjevant, wound healing, tissue engineering, and gene delivery. ${ }^{21-26}$

This study has focused on determining the in vitro cytotoxicity of CS in MDA-MB-231, T47D and MCF-7 breast cancer cell lines and its underlying mechanism of action. Furthermore, the in vitro binding characteristics of CS-DNA were explored by using various spectroscopic techniques.

\section{Experimental}

\section{Materials and cells}

CS (Sigma 448869, low molecular weight 50-190 kDa, 85\% deacetylate), MTT (3-(4,5-dimethyl-2-thiazolyl)-2,5-diphenyltetrazolium bromide), ethidium bromide (EB), acridine orange (AO), Phosphate Buffer Saline (PBS), dimethyl sulfoxide (DMSO), RNAase A, propidium iodide (PI), agarose, DCFH, and rhodamine 123 were supplied by Sigma-Aldrich chemical Co. (St. Louis Mo, USA). MDA-MB-231, MCF-7, T47D and L929 cell lines were purchased from National Cell Bank of Iran (Pasteur Institute, Iran). RPMI-1640, fetal bovine serum (FBS), trypsinEDTA, penicillin, and streptomycin were purchased from Gibco. The Annexin V-FITC apoptosis detection kit was supplied from BioVision, in situ cell death detection kit, fluorescein was obtained from Roche and Caspase-3 colorimetric assay kit was purchased from BIOMOL International, USA.

\section{Preparation of chitosan and DNA solutions}

High molecular weight DNA was extracted from rat hepatocyte using standard procedure ${ }^{27}$ (all experiments were performed in compliance with the guidelines of Tehran University of medical sciences National Ethics Committee in Biomedical Research) and $1 \mathrm{mg} \mathrm{m}{ }^{-1}$ DNA stock solutions were prepared in phosphate buffer $(0.1 \mathrm{M}, \mathrm{pH}=7.4)$. Extracted DNA quality control was performed by running samples on $0.8 \%$ agarose gel to confirm high molecular weight and samples with 260/280 absorbance ratios $\geq 1.8$ were accepted as pure DNA. Chitosan stock solution ( $1 \mathrm{mg}$ $\mathrm{ml}^{-1}$ ) was prepared as described previously. ${ }^{28}$ Briefly, $0.4 \mathrm{~g}$ of CS was dissolved in $40 \mathrm{ml} \mathrm{1 \%}(\mathrm{w} / \mathrm{w})$ acetic acid solution. The solution was sonicated using a $30^{\circ} \mathrm{C}$ ultrasonic bath (Bandlin, Germany) at $140 \mathrm{~W}$ for $5 \mathrm{~min}$ and stirred overnight at room temperature, until complete dissolution. Aliquots were stored at $4{ }^{\circ} \mathrm{C}$ until later use. Prior to experiment, CS stock solutions were filtered, and $\mathrm{pH}$ was adjusted to 7.4 with $0.1 \mathrm{~N} \mathrm{NaOH}$. All DNA binding experiments were performed in phosphate buffer $(0.1 \mathrm{M}, \mathrm{pH}=7.4)$.

\section{Cell lines and culture}

MDA.MB.231 (claudin low), MCF-7 (luminal A), T47D (luminal A) breast cancer cell lines ${ }^{29}$ and normal fibroblast cell line (L929) were maintained in RPMI-1640 medium supplemented with $10 \%$ FBS and antibiotics $\left(100 \mathrm{U} \mathrm{ml}^{-1}\right.$ penicillin and $100 \mu \mathrm{g}$ $\mathrm{ml}^{-1}$ streptomycin) at $37{ }^{\circ} \mathrm{C}$ under humidified air containing $5 \% \mathrm{CO}_{2}$ and were passaged using trypsin/EDTA (Gibco) and phosphate buffered saline (PBS) solution.

\section{Cytotoxicity assay by MTT in MDA-MB-231, T47D, MCF-7 and L929 cells}

The in vitro cytotoxicity of CS was determined in MDA-MB-231, MCF-7, T47D, and L929 cell lines using MTT colorimetric cell viability assay. All the cells were seeded in a 96-well plate at a density of $1.4 \times 10^{4}$ cells per well and incubated in $5 \% \mathrm{CO}_{2}$ at $37{ }^{\circ} \mathrm{C}$ for $24 \mathrm{~h}$. Subsequently, cells were treated for another 24 , 48 and 72 hours with various concentrations of CS $(0-500 \mu \mathrm{g}$ $\mathrm{ml}^{-1}$ ). Control groups were treated with RPMI culture medium without CS. Cells morphological changes were observed after $24 \mathrm{~h}$ and imaged by phase-contrast microscope. After treatment, in order to measure the effects of different concentrations of CS on cells proliferation, the medium was removed and $200 \mu \mathrm{l}$ per well of MTT solution (0.5 mg ml $\mathrm{mg}^{-1}$ in PBS) was added and incubated at $37{ }^{\circ} \mathrm{C}$ for an additional $4 \mathrm{~h}$. The supernatant was discarded and $100 \mu \mathrm{l}$ per well DMSO was added to dissolve the MTT-formazan crystals produced by the viable cells. Viability was determined by measuring absorbance at $492 \mathrm{~nm}$ using an ELISA reader (Model wave xs2, BioTek, USA). All experiments were done in triplicate and the concentration of CS required for $50 \%$ inhibition of viability $\left(\mathrm{IC}_{50}\right)$ was calculated by using logarithm-transformed linear regression method. In brief, cell proliferation inhibition was calculated as follow: \% cell proliferation inhibition $=(492 \mathrm{~nm}$ mean absorption in control wells - $492 \mathrm{~nm}$ mean absorption of treated wells)/492 $\mathrm{nm}$ mean absorption of control wells $\times 100$. The results were then plotted against logarithmic scale CS concentrations in Excel.

\section{MDA-MB-231, T47D and MCF-7 cells AO/EB fluorescent staining}

In order to evaluate apoptosis qualitatively, double staining method was employed. MDA-MB-231, T47D, and MCF-7 were seeded in 6 well plates and treated with the $\mathrm{IC}_{50}$ concentration of CS for $24 \mathrm{~h}$. After treatment cells were washed with PBS and a solution containing $\mathrm{EB} / \mathrm{AO}$ was added, the stained cells were immediately visualized and imaged under a fluorescence microscope (Axioskop 2 plus, Zeiss, Germany). The distinction between viable, apoptotic, and necrotic cells is based on the differences between dye permeability into intact cell membrane. Green cells represent viable cells with typically 
structured chromatin and stain only by $\mathrm{AO}$, orange and green cells with condensed chromatin are late and early apoptotic cells and stained with both $\mathrm{AO}$ and $\mathrm{EB}$, finally necrotic cells are orange and stained with EB. ${ }^{10}$ Ten photos were taken of randomly selected areas of the stained slides to ensure the obtained data were representative.

\section{Flow cytometric analysis of apoptosis}

CS induced apoptosis was verified by flow cytometry (Partec PAS, Germany) using a commercially available Annexin V-FITC/ PI apoptosis detection kit (BioVision). $2.1 \times 10^{6}$ MDA-MB-231 cells $\left(3.5 \times 10^{5}\right.$ cells per well) were seeded into 6-well plates and treated with the $\mathrm{CS} \mathrm{IC}_{50}$ for $4 \mathrm{~h}$, afterward, cells were harvested and washed with PBS. Cell pellets were labeled with PI, and FITC conjugated Annexin V according to the protocol described by the kit manufacturer. Stained cells were analyzed by flow cytometry.

\section{TUNEL assay for measurement of in situ DNA fragmentation}

TUNEL (terminal deoxyribonucleotidyl transferase-mediated dUTP nick-end labeling) assay was used for detection of DNA fragmentation, a key event in apoptosis, using in situ cell death detection kit, fluorescein (Roche) according to the manufacturer's instruction. Cells were cultured and treated with $\mathrm{CS} \mathrm{IC}_{50}$ concentration for $4 \mathrm{~h}$, then were fixed in $4 \%$ paraformaldehyde and permeabilized with $1 \%$ Triton $\mathrm{X}-100$ and $0.1 \%$ sodium citrate. Cells were suspended in PBS and mean cell fluorescence of 10000 cells and percentage of TUNEL-positive cells was analyzed using flow cytometer.

\section{Assessment of changes in mitochondrial transmembrane potential}

Measurement of mitochondrial membrane potential changes $\left(\Delta \Psi_{\mathrm{m}}\right)$ was performed with rhodamine 123 fluorescent dye. At first, MDA-MB-231 $\left(3.5 \times 10^{5}\right.$ cells per well) cells were cultured in six-well plates and treated with 70 and $145 \mu \mathrm{g} \mathrm{ml} \mathrm{m}^{-1}$ chitosan for $12 \mathrm{~h}$. Subsequently, cells were trypsinized, centrifuged, washed with PBS and incubated with rhodamine 123 staining solution ( $400 \mu \mathrm{l} 50 \mu \mathrm{M}$ in PBS) at $37^{\circ} \mathrm{C}$ for $30 \mathrm{~min}$. Finally, after three washes with PBS, samples were ready for analysis. Percentage of depolarized cells was determined by FACS Analyzer with excitation/emission at $488 / 525-530 \mathrm{~nm}$ in the FL1 and FL2 channels respectively.

\section{Quantitation of intracellular ROS formation by DCFH-DA labeling}

Intracellular ROS generation was measured by staining cells with fluorescent probe 2,7-dichlorofluorescein diacetate (DCFH-DA). This probe enters cells by simple diffusion and is hydrolyzed into nonfluorescent dichlorofluorescein (DCFH) by means of intracellular esterases. Subsequently, dichlorofluorescein (DCFH) is oxidized to highly fluorescent dichlorofluorescein (DCF) by ROS. Thus, the fluorescence intensity is proportional to the amount of peroxides produced by the cells. In brief, MDA-MB-231 cells $\left(1 \times 10^{5}\right.$ cells per well $)$ were treated with 70, 145 and $290 \mu \mathrm{g} \mathrm{ml} \mathrm{g}^{-1} \mathrm{CS}$ for $12 \mathrm{~h}$. Afterward, cells were harvested, washed twice, resuspended in PBS, and incubated with DCFH-DA at a final concentration of $20 \mu \mathrm{M}$ for $30 \mathrm{~min}$ at $37^{\circ} \mathrm{C}$ in the dark. The DCF fluorescence intensity was measured by a flow cytometer at an excitation wavelength of 485-495 nm and fluorescence emission was measured in channel FL-1 at $525-530 \mathrm{~nm}$. The results were expressed as percentage of the mean fluorescence intensity of FL-1 of the control group.

\section{DNA oxidation analysis}

Genomic DNA of MDA-MB-231 cells treated for $2 \mathrm{~h}$ with 145 and $290 \mu \mathrm{g} \mathrm{ml}^{-1} \mathrm{CS}$ and untreated controls were extracted according to standard phenol/chloroform extraction procedure. ${ }^{27}$ 8-Oxo detection Elisa kit (Cayman chemical 589320) was used to measure the concentration of the major product of DNA oxidation (8-oxo-2'-deoxyguanosine) in each sample according to manufacturer's protocol. In brief $5 \mu \mathrm{g}$ gDNA was subjected to the Elisa kit in duplicates after digestion with nuclease P1 (sigma N8630) and treatment with alkaline phosphatase (NEB M0290S) in a total volume of $50 \mu \mathrm{l}$. The amounts of 8-oxo were then reported in $\mathrm{pg} \mathrm{ml}^{-1}$.

\section{Caspase-3 activity assay}

Caspase-3 activity was measured using colorimetric assay kit (BIOMOL International, USA), according to the manufacturer's instruction. Briefly, MDA-MB-231 cells $\left(1 \times 10^{6}\right)$ were treated with 70, 145 and $290 \mu \mathrm{g} \mathrm{ml} \mathrm{g}^{-1}$ of CS for $4 \mathrm{~h}$ and then each sample was harvested and washed with PBS. The cells were incubated with lysis buffer on ice, and the protein concentration of each sample was determined using the Bradford method. Equivalent amounts of proteins for each sample were incubated with the appropriate caspase- 3 substrate and after $4 \mathrm{~h}$; the absorbance at $405 \mathrm{~nm}$ was measured using a microplate reader.

\section{Cell cycle analysis}

Cell cycle distribution was examined by measuring the DNA content of nuclei labeled with propidium iodide (PI). $3.5 \times 10^{5}$ MDA-MB-231 cells were treated with 145 and $290 \mu \mathrm{g} \mathrm{ml}^{-1}$ of CS for $24 \mathrm{~h}$. After treatment, cells were harvested by centrifugation, washed with $1 \mathrm{ml}$ cold PBS, centrifuged, and fixed in $70 \%$ cold ethanol at $4{ }^{\circ} \mathrm{C}$ for $24 \mathrm{~h}$. Subsequently, cells were washed twice and treated with RNase A $\left(20 \mu \mathrm{g} \mathrm{ml}^{-1}\right)$ and PI $\left.(20 \mu \mathrm{g} \mathrm{ml})^{-1}\right)$ for $30 \mathrm{~min}$ at $37^{\circ} \mathrm{C}$ in the dark. At the end, cell cycle distribution analysis was performed using flow cytometry and the percentages of cells at G1, S and G2/M phases were calculated by FlowJo software (Version 7.6.1).

\section{UV-visible spectroscopy}

UV absorbance measurements were recorded on Carry spectrophotometer (100 Bio-models, Australia) using quartz cuvettes. Absorption experiments were done by titrating varying concentrations of CS $\left(9-150 \mu \mathrm{g} \mathrm{ml} \mathrm{m}^{-1}\right)$ against a constant concentration of DNA $\left(50 \mu \mathrm{g} \mathrm{ml}^{-1}\right)$. The UV spectra of CS solution, DNA solution, and CS-DNA complex were recorded in the 190-400 $\mathrm{nm}$ range. The spectra of each sample were 
recorded in $30 \mathrm{~min}$ at $298 \mathrm{~K}$. Blank used for each CS-DNA sample, contained the same amount of CS without any DNA.

\section{Fluorescence studies}

Fluorescence experiments were carried out on a Carry eclipse spectrofluorometer (Australia) using $1 \mathrm{~cm}$ quartz cells. In competitive displacement assay with $\mathrm{EB}$, a solution containing EB $(2.6 \mu \mathrm{M})$ and DNA $\left(50 \mu \mathrm{g} \mathrm{ml}^{-1}\right)$ was titrated with increasing concentrations of CS. EB-DNA complex was excited at $500 \mathrm{~nm}$ and emission spectra were recorded from 530-700 nm, with the widths of both the excitation and the emission slits set at $10 \mathrm{~nm}$.

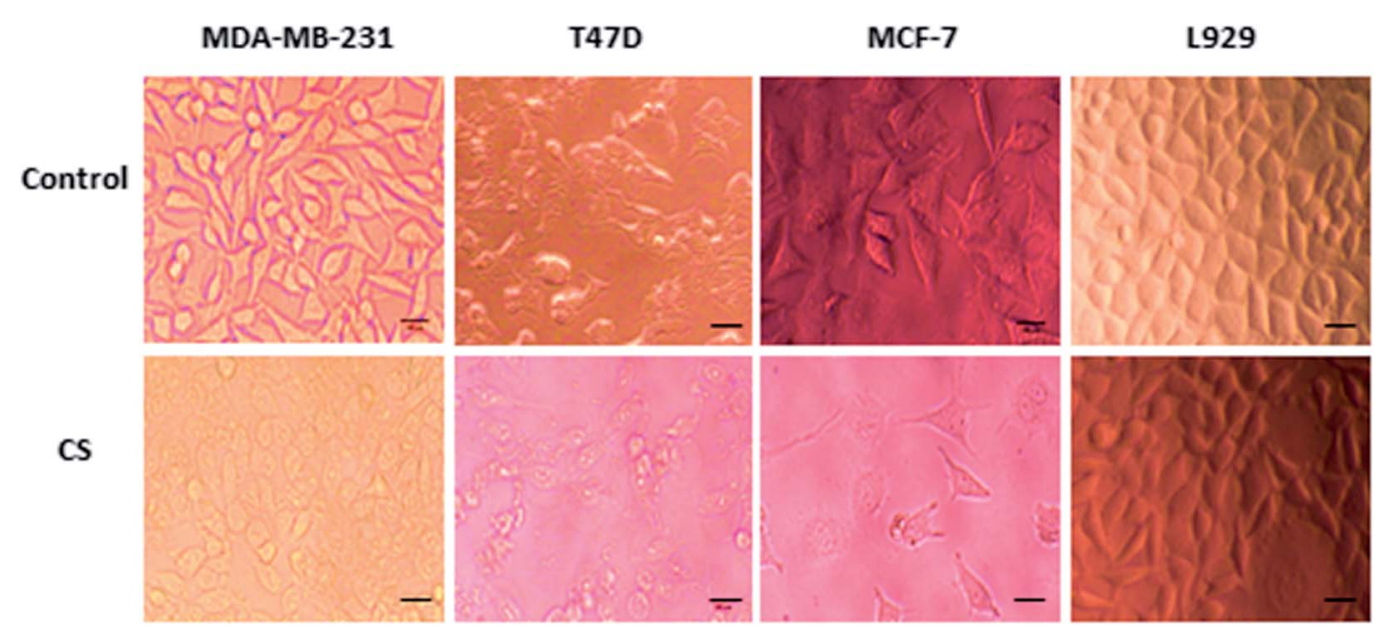

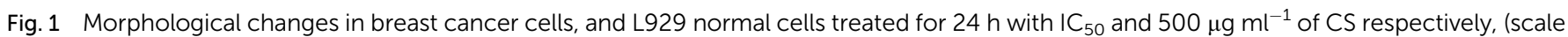
bars represent $50 \mu \mathrm{m})$.
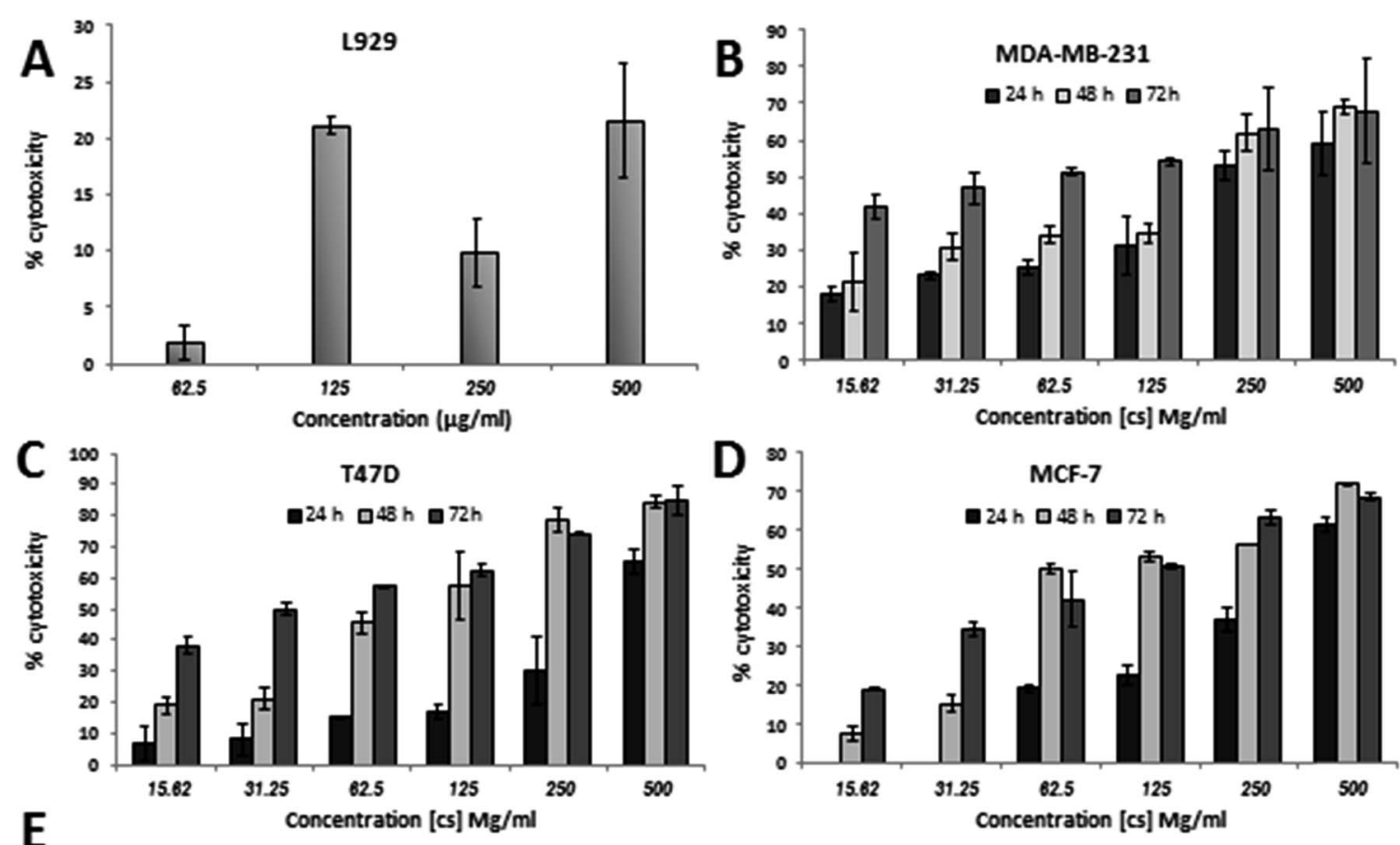

\begin{tabular}{|c|c|c|c|c|c|c|c|c|c|c|}
\hline Compound & \multicolumn{10}{|c|}{ ICSO ( $\mu \mathrm{g} / \mathrm{ml})$} \\
\hline \multirow{3}{*}{ CS } & \multicolumn{3}{|c|}{ MDA-MB-231 } & \multicolumn{3}{|c|}{ T47D } & \multicolumn{3}{|c|}{ MCF-7 } & \multirow{2}{*}{$\begin{array}{c}1929 \\
48 h \\
\end{array}$} \\
\hline & $24 \mathrm{~h}$ & $48 \mathrm{~h}$ & $72 \mathrm{~h}$ & $24 \mathrm{~h}$ & $48 \mathrm{~h}$ & $72 \mathrm{~h}$ & $24 \mathrm{~h}$ & $48 \mathrm{~h}$ & $72 \mathrm{~h}$ & \\
\hline & $291.9 \pm 4.2$ & $156.8 \pm 3.9$ & $49.7 \pm 5.8$ & $510.1 \pm 4.6$ & $83.2 \pm 4.4$ & $36.75 \pm 2$ & $362.3 \pm 1.3$ & $131.6 \pm 1$ & $113.1 \pm 2.1$ & NA \\
\hline
\end{tabular}

Fig. 2 CS cytotoxicity on (A) L929 (B) MDA-MB-231 (C) T47D (D) MCF-7 cells, as determined by MTT assay. Results indicate that CS is selectively cytotoxic towards cancer cell lines. (E) Data are represented as mean \pm SD of at least three independent tests. 


\section{Circular dichroism (CD) studies}

CD spectra of pure DNA $\left(100 \mu \mathrm{g} \mathrm{ml}^{-1}\right)$, CS $\left(75 \mu \mathrm{g} \mathrm{ml}^{-1}\right)$ and CSDNA were recorded using Aviv circular dichroism 215 spectrophotometer (USA) at $298 \mathrm{~K}$. The CD spectra were recorded at wavelengths between 200-320 nm. Background spectrum of phosphate buffer solution was subtracted from the spectra of DNA, CS, and CS-DNA complex. Then, the spectra of CS-DNA samples were subtracted from the spectra of CS in the same condition.

\section{Statistical analysis}

Experimental data processing was carried out using Microsoft Excel 2013 software, and results were presented as the mean \pm standard deviation of three or more independent experiments. The significant differences between means were determined by $t$-test when statistical significance was $P$ value $\leq 0.05$.

\section{Results and discussion}

\section{Growth inhibitory effect of CS on MCF-7, T47D and MDA-MB-} 231 breast cancer cells

To investigate the inhibitory effect of CS, three human breast cancer cell lines (MDA-MB-231, T47D, MCF-7) and normal fibroblast L929 cells were treated with 15.62-500 $\mu \mathrm{g} \mathrm{ml}^{-1} \mathrm{CS}$ for
24, 48 and 72 hours. Initial microscopic examination of the cells after $24 \mathrm{~h}$ demonstrated vivid morphological alterations in cancer cells such as cell rounding, detachment, and cytoplasmic vacuolation indicating CS cytotoxicity (Fig. 1). The physical and biologic properties of chitosan are dependent on its molecular weight (MW) and degree of deacetylation (DD). In previous studies, the cytotoxicity of chitosan as a soluble molecule has been reported as a function of MW, DD, and concentration. ${ }^{30}$ In this study, growth inhibition was measured by MTT assay and $\mathrm{IC}_{50} \mathrm{~S}$ was calculated. As it is shown in (Fig. 2), exposure of three breast cancer cell lines to low $M_{\mathrm{w}}$ CS with $85 \%$ DD clearly decreased cellular viability in a dose and timedependent manner while inducing a much less toxic effect on normal L929 cells, indicating a favorable selectivity towards cancer cells. Among the breast cancer cell lines tested, MDAMB-231 is a highly invasive, basal-like phenotype ${ }^{31}$ and often considered as an apoptosis-resistant cell line. ${ }^{32}$ Therefore, to investigate the mechanism by which CS decreases cell viability in breast cancer cells, we focused on MDA-MB-231 cells.

\section{CS induces apoptosis in MDA-MB-231 cells}

In order to verify apoptosis as the underlying mechanism of CS growth inhibitory effect, AO/EB staining, Annexin V-FITC/PI
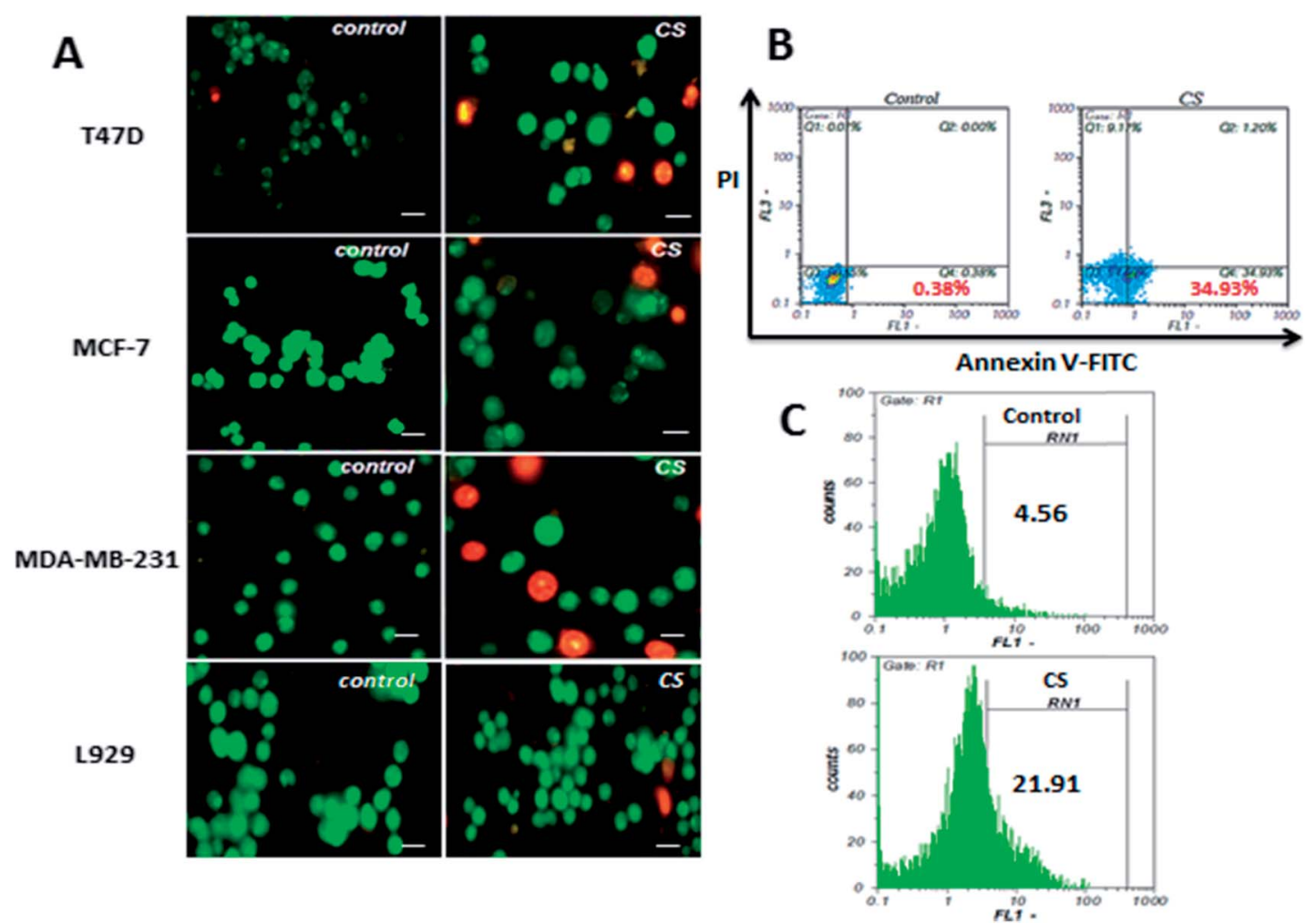

Fig. 3 (A) MDA-MB-231, T47D, and MCF-7 cells after $24 \mathrm{~h}$ treatment and staining with AO/EB showed clear apoptotic morphological alterations, while, L929 normal cells did not exhibit significant changes (scale bars represent $50 \mu \mathrm{m}$ ). (B) Annexin V-FITC/PI flow cytometry analysis of MDAMB-231 cells treated with CS IC 50 for $4 \mathrm{~h}$. The lower left quadrant represents intact viable cells (Annexin-FITC and PI negative). The lower right quadrant represents early apoptotic cells (Annexin-FITC positive and PI negative). The upper right region represents late apoptotic cells or secondary necrotic cells (Annexin-FITC and PI positive). (C) TUNEL staining flow cytometry histograms of MDA-MB-231 cells treated with CS IC ${ }_{50}$ for $4 \mathrm{~h}$ and untreated control. An evident shift of the cell population (21.91\%) to the right compared to control $(4.56 \%)$ indicates a significant apoptotic cell population in CS treated cells. 
staining, and TUNEL assay were performed. In AO/EB staining of MDA-MB-231, T47D and MCF-7 cells as shown in Fig. 3A, cell nuclei and cell membrane integrity of control samples did not change significantly, while treated samples showed different extents of chromatin condensation, nuclear fragmentation, and destruction of cell membrane integrity. To further confirm apoptosis, MDA-MB-231 cells were treated with $\mathrm{IC}_{50}$ concentration $\left(290 \mu \mathrm{g} \mathrm{ml} \mathrm{m}^{-1}\right)$ of $\mathrm{CS}$ for $4 \mathrm{~h}$ and apoptosis induction was evaluated by Annexin V-FITC/PI double staining. Annexin V-FITC is capable of binding tightly to phosphatidylserines externalized to outer plasma membrane during early stages of apoptosis, and simultaneously, propidium iodide is included to differentiate between apoptotic and necrotic cells. This approach allows a further distinction of early apoptotic (Annexin $\mathrm{V}+/ \mathrm{PI}-$ ) and late apoptotic/necrotic (Annexin V+/PI+) cells. The results (Fig. 3B) indicated that CS markedly induces apoptosis, and the population of early apoptotic cells was $34 \%$, higher than the untreated samples. DNA fragmentation is a major hallmark of apoptosis which reflects the endonuclease activity and can be evaluated quantitatively by TUNEL assay. As shown in Fig. 3C, DNA fragmentation in MDA-MB-231 cells treated with $\mathrm{IC}_{50}$ concentration of CS for $4 \mathrm{~h}$, quantified by flow cytometry and compared to untreated control cells $21.9 \%$ apoptosis was observed.

\section{CS induces apoptosis via ROS generation}

In order to examine the changes in intracellular ROS level and ROS involvement in apoptosis induced by CS, DCFH-DA assay was conducted on MDA-MB-231 cells treated with 70, 145 and $290 \mu \mathrm{g} \mathrm{ml}^{-1} \mathrm{CS}$ for $12 \mathrm{~h}$ and 9.29, 13.40 and $20.50 \%$ increase in ROS generation was observed respectively, whereas, untreated cells showed only 3.69\% DCF positive cells (Fig. 4A). These results indicate that $\mathrm{CS}$ is able to trigger ROS generation in a dose-dependent manner in treated cells.

\section{DNA oxidation}

Increased level of ROS in CS treated cells may have caused DNA damage via DNA oxidation. Therefore, to investigate the effect of CS on DNA oxidation, accumulation of 8-oxoguanine (8-oxo) which is the most abundant oxidative base lesion in genomic DNA was evaluated. As shown in Fig. 4B, treatment of MDA-MB-231 cells with 145 and $290 \mu \mathrm{g} \mathrm{ml}^{-1} \mathrm{CS}$ for $2 \mathrm{~h}$ has resulted in formation of 350.9 and $553.4 \mathrm{pg} \mathrm{ml}^{-1}$ 8-oxo respectively, which is significantly higher in comparison to untreated cells (131.6 $\mathrm{pg} \mathrm{ml}^{-1}$ ).
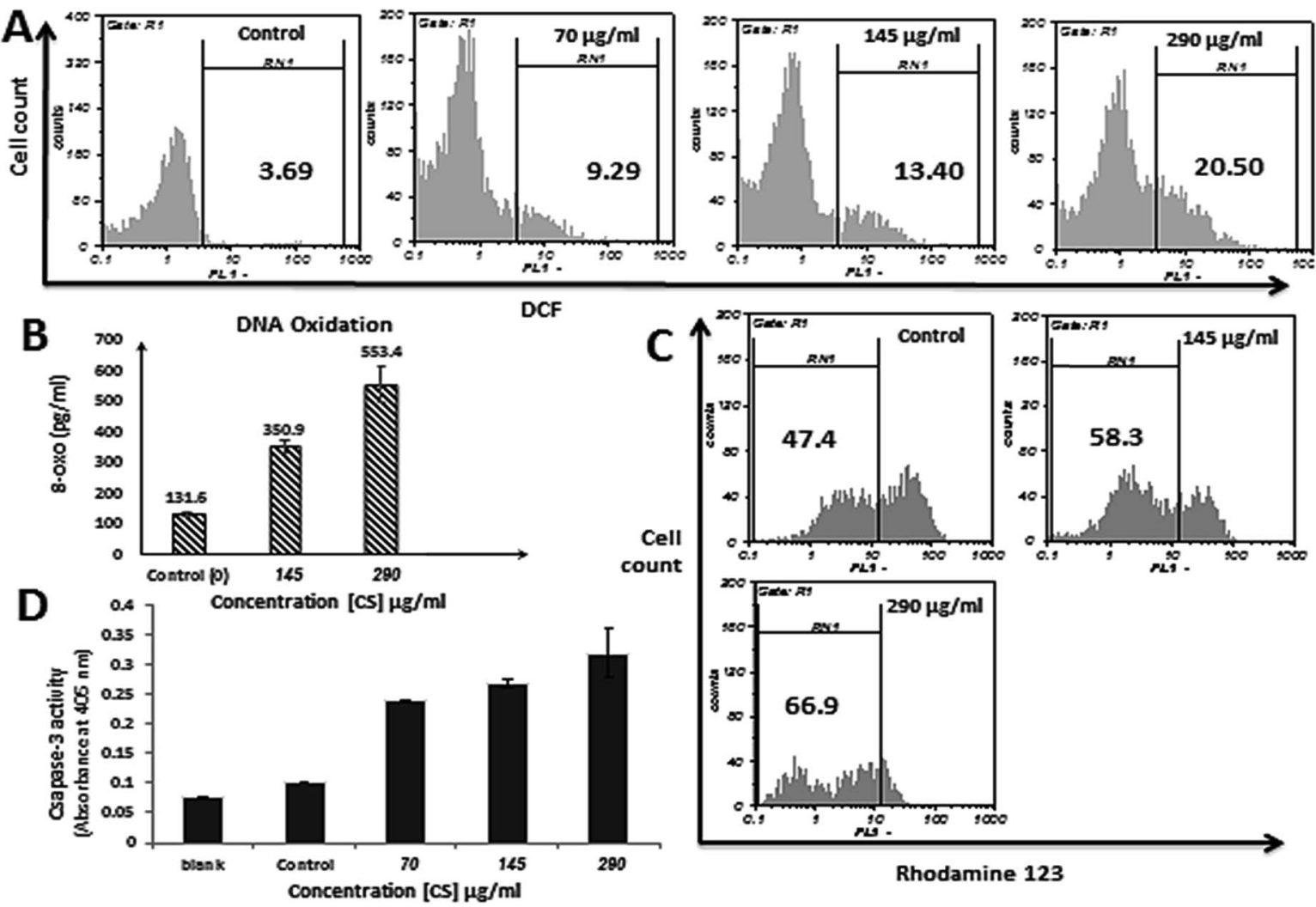

Fig. 4 Effect of CS on MMP, ROS generation, DNA oxidation and caspase-3 activity in MDA-MB-231 cells. (A) ROS level in MDA-MB-231 cells was monitored after incubation with 70,145, and $290 \mu \mathrm{g} \mathrm{ml}^{-1} \mathrm{CS}$ with flow cytometry using DCFH-DA fluorescent dye. The fluorescence intensity of treated cells was recorded in FL-1 channel. (B) MDA-MB-231 cells treated with increasing amounts of CS produced increasing amounts of 8 -oxo compared to untreated control cells. (C) The collapse of mitochondrial membrane potential. The $\Delta \Psi_{m}$ of MDA-MB-231 cells reduces increasingly after incubation with 145 and $290 \mu \mathrm{gl}^{-1} \mathrm{CS}$ for $12 \mathrm{~h}$, as assessed by rhodamine 123 staining and FACS analysis. (D) Caspase-3 activation assessment after $4 \mathrm{~h}$ treatment with CS $\left(70,145\right.$ and $\left.290 \mu \mathrm{g} \mathrm{ml}^{-1}\right)$. 
CS exposure reduces mitochondrial membrane potential $\left(\Delta \Psi_{\mathbf{m}}\right)$

$\Delta \Psi_{\mathrm{m}}$ is a key event in mitochondrial apoptotic pathway, and reduces along with the increase in mitochondrial membrane permeability. A dose-dependent increase in the mean percentage of depolarization and reduction of $\Delta \Psi_{\mathrm{m}}$ after treatment with CS was observed, which indicates the mitochondrial pathway involvement in the apoptosis induced by CS. Treatment of MDAMB-231 cells for $12 \mathrm{~h}$ with 145 and $290 \mu \mathrm{g} \mathrm{ml} \mathrm{m}^{-1}$ of CS resulted in 10.9 and $19.5 \%$ decrease in functional mitochondria respectively, compared to untreated cells (Fig. 4C).

\section{CS increases caspase-3 activity in MDA-MB-231 cells}

Caspase-3 is probably the best understood executioner in apoptosis and is crucial for some typical hallmarks of apoptosis such as apoptotic chromatin condensation, DNA fragmentation, and formation of apoptotic bodies. In this study, caspase-3 activation was evaluated in MDA-MB-231 cells incubated with 70,145 , and $290 \mu \mathrm{g} \mathrm{ml} \mathrm{m}^{-1}$ of CS for $4 \mathrm{~h}$, and compared to the negative control, 2.3, 2.6, and 3.1 times increase in caspase-3 activity was observed respectively (Fig. 4D). This indicates that CS has induced the expression of this caspase, and the apoptosis could be triggered through a caspase-dependent process.

\section{CS treated MDA-MB-231 cells exhibit cell cycle arrest in S} phase

To further investigate the mechanism, underlying the CS inhibitory activity on breast cancer cells, we investigated its effect on cell cycle progression. Hence, we monitored cell cycle phase distribution of MDA-MB-231 cells after treating with 50\% $\mathrm{IC}_{50}$ and $\mathrm{IC}_{50}$ concentrations of $\mathrm{CS}$ for $24 \mathrm{~h}$, and subsequently, cell cycle profiles were analyzed by measuring the DNA content using flow cytometry. As shown in Fig. 5, treating cells with 145 and $290 \mu \mathrm{g} \mathrm{ml}^{-1}$ of CS caused substantial inhibition of cell cycle progression. The cells population in S phase increased from 8 to $21 \%$, and an increase in subG1 population was observed. There was also a decrease in the number of cells in the G1 and G2/Mphases. These results suggest that CS disturbs cell cycle progression, leading to the accumulation of cells in S-phase.

\section{UV-visible spectra observation of CS-DNA complexes}

UV-visible absorption spectrum is a basic, most common and simple method, which helps in illustrating the structural changes and also sheds light on complex formation. ${ }^{33,34}$ In this study, this method was used to observe the changes of DNA absorbance spectrum in the presence of different concentrations of CS. The absorption spectra of DNA scanned in UV region in the absence and presence of different concentrations of $\mathrm{CS}\left(9-150 \mu \mathrm{g} \mathrm{ml}^{-1}\right)$ at $\mathrm{pH}=7.4$ as shown in Fig. 6A1 and A2. In this region, DNA displays a peak at $260 \mathrm{~nm}$ (indole groups) and $210 \mathrm{~nm}$ (sugar-phosphate groups), while, CS has no absorption in this area. When different concentrations of CS was added to DNA, hyperchromism was observed without any noticeable shift in the position of maximum absorption peak, which clearly indicated the formation of complex between DNA and $\mathrm{CS}^{35}$ The exact binding mode cannot be proven simply by

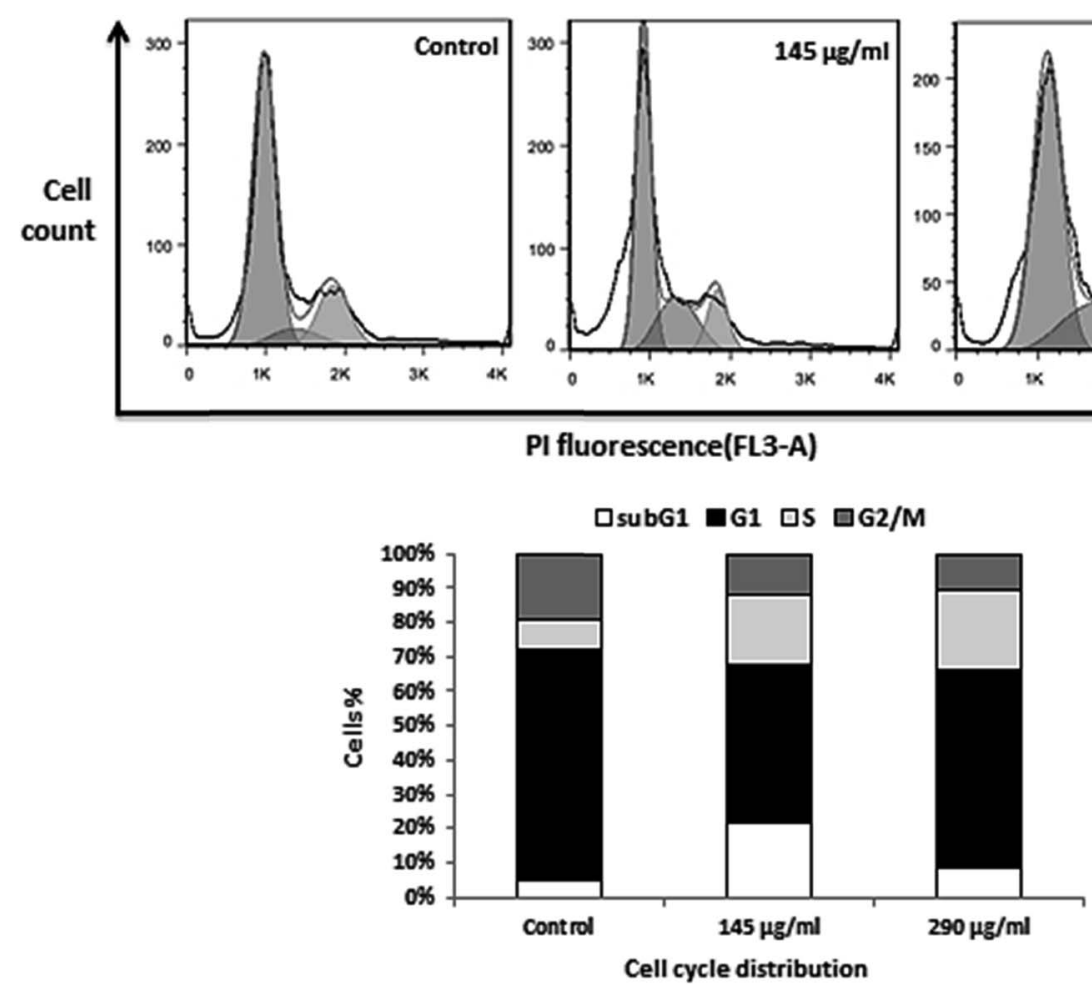

Fig. 5 DNA histogram of MDA-MB-231 cells treated with CS 50\% IC $50\left(145 \mu \mathrm{g} \mathrm{ml}^{-1}\right)$ and IC $50\left(290 \mu \mathrm{g} \mathrm{ml}^{-1}\right)$ for $24 \mathrm{~h}$. Effect of CS on cell cycle distribution in MDA-MB-231 cells was analyzed using flow cytometry, and the chart represents the percentage of cell populations in MDA-MB-231 cells treated with CS. 
this technique, hence, further tests were necessary to explore the mode of interaction.

\section{Competitive displacement fluorescence assay}

To further explore the binding mode of CS with DNA, competitive displacement fluorescence assay was performed. As the intrinsic fluorescence of DNA is very weak, we used Ethidium Bromide (EB) as a fluorescent probe to study the interaction between DNA and CS. ${ }^{36}$ In aqueous solutions, free EB is not considerably fluorescent. However, in the presence of DNA, it is strongly emissive due to its intercalation within the DNA base pairs. Since EB intercalates DNA, competitive displacement of EB on the addition of drug will be indicative of an intercalative binding mode. ${ }^{37}$ In this study, fluorescence quenching studies were performed by keeping the fixed concentration of DNA (50 $\left.\mu \mathrm{g} \mathrm{ml} \mathrm{m}^{-1}\right)$ and varying amounts of CS $\left(0-448 \mu \mathrm{g} \mathrm{ml}^{-1}\right)$. CS did not fluoresce at $600 \mathrm{~nm}$ when excited at $500 \mathrm{~nm}$, and as the emission spectra of the DNA-EB system is shown in Fig. 6B1-B3, with increasing concentrations of $\mathrm{CS}$, a remarkable reduction in fluorescence of DNA-EB system was observed, which suggests CS has substituted EB in the DNA-EB system and dissociated the EB into the solvent. This leads to a decrease in the fluorescence intensity of the DNA-EB system and has provided direct evidence in support of intercalative binding mode.

Moreover, the fluorescence quenching data were analyzed to obtain the quenching constant $\left(K_{\mathrm{SV}}\right)$ by using the Stern-Volmer equation: ${ }^{38}$

$$
\left(F_{0} / F\right)=1+K_{\mathrm{SV}}[\mathrm{Q}]
$$

where, $F_{0}$ and $F$ are the steady-state fluorescence intensities in the absence and presence of quencher (CS), respectively. $K_{\mathrm{SV}}$ is the Stern-Volmer quenching constant, and [Q] is the concentration of the quencher. Hence, the slope of linear regression of $F_{0} / F v s$. [Q] plot yields the $K_{\mathrm{SV}}$ value. The quenching constant $\left(K_{\mathrm{SV}}\right)$ of EB by CS in the presence of DNA was calculated to be $2.5 \times 10^{5} \mathrm{M}^{-1}$ which is consistent with $K_{\mathrm{SV}}$ of most of the intercalating agents, ${ }^{12}$ and suggesting that CS molecules have intercalated into the base pairs of DNA. Furthermore, linear Stern-Volmer plots were obtained for CS, suggesting that dynamic quenching process might have occurred. The constant parameter ( $K$ and $n$ ) can be calculated using the following equation:

$$
\log \left(F_{0}-F\right) / F=\log K_{\mathrm{a}}+n \log [\mathrm{Q}]
$$
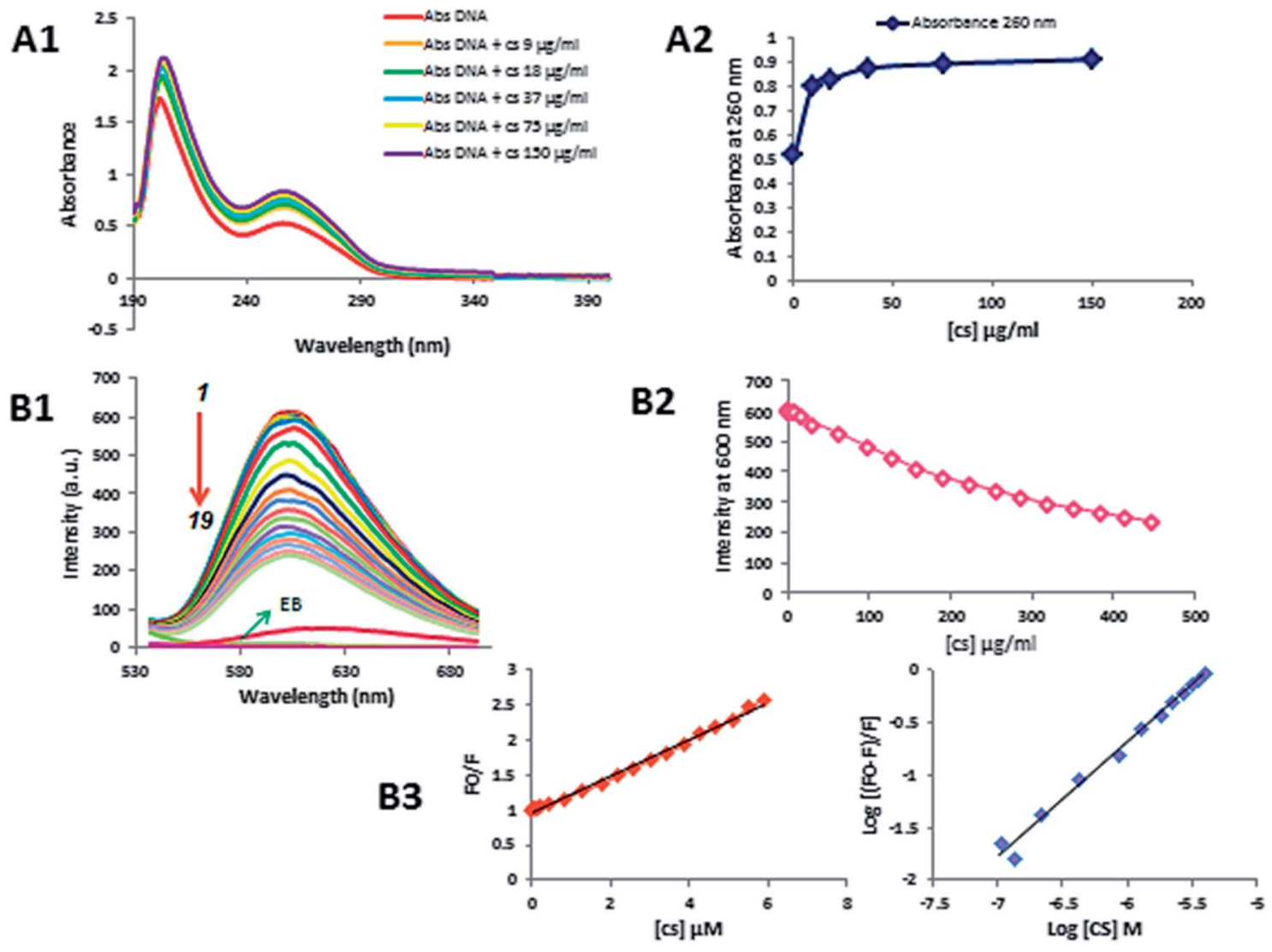

Fig. 6 Determining the CS mode of action with gDNA. (A1) UV spectra of DNA and DNA-CS complex in the constant concentration of DNA (50 $\left.\mu \mathrm{g} \mathrm{m}^{-1}\right)$ and increasing amounts of CS $\left(9-150 \mu \mathrm{g} \mathrm{ml}^{-1}\right)$, and (A2) quantities of DNA absorbance at $260 \mathrm{~nm}$ after the spectra of CS-DNA samples were subtracted from the spectra of CS in the same condition. Competitive displacement assays (B1 \& B2), fluorescence titration of EB-DNA complex with CS. Fluorescence intensity decreased gradually with subsequent addition of CS $\left(0-448 \mu \mathrm{g} \mathrm{ml} \mathrm{m}^{-1}\right)$. EB-DNA complex was excited at $500 \mathrm{~nm}$ and emission spectra were recorded from $530-700 \mathrm{~nm}$. (B3) Stern-Volmer plot for measuring quenching constants parameters $\left(K_{\mathrm{SV}}, K_{\mathrm{a}}\right.$ and $n$ ). 


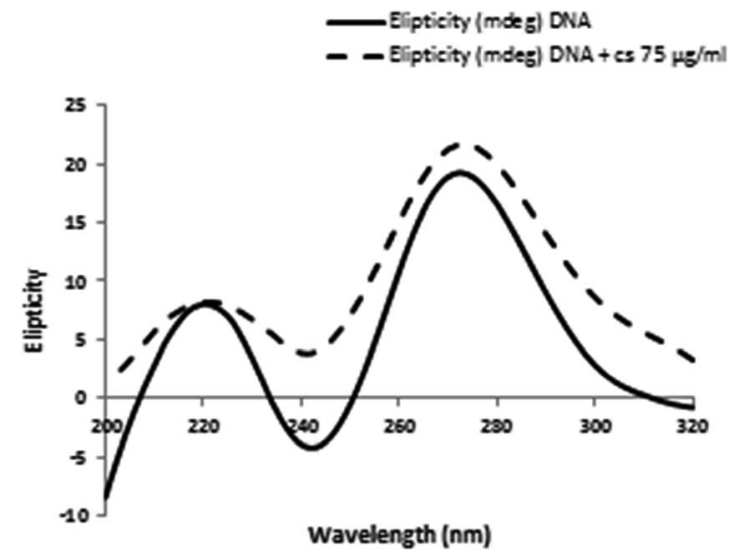

Fig. 7 CD spectra of DNA conformational changes induced by CS were assessed by incubating DNA $\left(100 \mu \mathrm{g} \mathrm{ml}^{-1}\right)$ in $0.1 \mathrm{M}$ phosphate buffer $(\mathrm{pH}=7.4)$ in the presence of $75 \mu \mathrm{g} \mathrm{m}^{-1} \mathrm{CS}$ at $298 \mathrm{~K}$.

The binding constant $\left(K_{\mathrm{a}}\right)$ is calculated for the quantitative measurements of binding of CS with DNA. As shown in Fig. 6B3, the plot is linear and the binding constant $\left(K_{\mathrm{a}}\right)$ for this interaction is $7.6 \times 10^{5} \mathrm{M}^{-1}$, which indicates that CS has a high affinity towards dsDNA, and number of binding sites $(n)$ of the CS-DNA complex is 1.09. These parameters of the CS-DNA complex suggesting that CS can intercalate into DNA base pairs strongly. ${ }^{39}$

\section{Circular dichroism study}

To further confirm the interaction modes of the CS with DNA, the conformational changes of DNA in the absence and presence of small molecules was studied by CD spectroscopy. Generally, base stacking and right-handed helicity in B-form dsDNA creates a positive band at $275 \mathrm{~nm}$ and a negative band at $245 \mathrm{~nm}$ in $\mathrm{CD}$ spectrum respectively. ${ }^{40}$ Small molecules different binding modes of interaction with DNA may cause diverse perturbation in base stacking, which can be detected via changes in CD signals. Classical intercalation often leads to changes in the intensities of both bands due to enhancement of base stacking and stabilization of helicity, whereas simple groove binding and electrostatic interaction produce low or no perturbation on the base stacking and helicity bands. ${ }^{33}$ Fig. 7 shows that at the presence of CS, the intensity of the positive band at $275 \mathrm{~nm}$ and negative band at $245 \mathrm{~nm}$ increases remarkably, which indicates that CS mainly intercalates into DNA base pairs and enhances the base stacking.

\section{Conclusions}

Previous studies have reported the potential of CS to induce apoptosis in leukemia, gastric, bladder and breast cancer cells. However, underlying cellular and molecular mechanism for antitumor properties of CS has not been elucidated. ${ }^{23,41}$ In the present study, we demonstrated that CS is cytotoxic towards MDA-MB-231, MCF-7, and T47D breast cancer cell lines via inducing apoptosis, while, non-toxic to non-carcinogenic L929 cells. Our results indicate that CS may selectively inhibit the viability of breast cancer cells, which is a highly desirable property of potential anticancer agents. The mitochondriamediated cell death pathway also referred as the intrinsic apoptotic pathway is at the center of the apoptosis induced by the caspase signaling cascade activation, and plays a pivotal role in the apoptotic cell death induced by anti-cancer agents. High levels of ROS trigger mitochondrial permeability transition pore opening ( $\Delta \Psi_{\mathrm{m}}$ loss), which is an important downstream signal of ROS, and the release of pro-apoptotic factors and the activation of caspase-3. Caspase-3 activation subsequently leads to DNA breakage, nuclear chromatin condensation, and apoptosis. ${ }^{6,42-44}$ As our data show, CS has induced intrinsic mitochondria-mediated apoptosis in a caspase-3-dependent manner, accompanying collapse of mitochondrial membrane potential and ROS production from mitochondria into the cytoplasm. This indicates that mitochondrial dysfunction may have occurred during CS-induced MDA-MB-231 cells death.

Cancer cells proliferate relentlessly due to loss of cell cycle checkpoints that regulate the passage through the cell cycle. These check points monitor the integrity of DNA and ensure proper gene expression. Cell cycle analysis revealed an "Sphase" population increase in a concentration-dependent manner which indicates that $\mathrm{CS}$ can induce $\mathrm{S}$ phase cell cycle arrest in treated MDA-MB-231 cells. Besides, when MDAMB-231 cells were treated for $24 \mathrm{~h}$, an increase in cells in subG1 phase was observed. This suggests that CS might have induced apoptosis or DNA damage, which needs to be repaired before cell division took place. Since DNA replication is an essential phase of the cell cycle, and DNA is a bio-receptor for vast numbers of small molecules, it is considered a major biological target for anti-cancer agents. Intercalation of small molecules into DNA may be applied in therapeutic approaches to arrest cell proliferation and destroy tumor cells, or in the case of infected tissues, by preventing/inhibiting synthesis of DNA and gene transcription. ${ }^{45}$ Therefore, interaction properties of CS with DNA were investigated and the results were discussed. Previous studies have proposed that CS and its derivatives form complex with DNA by electrostatic interactions between primary amine groups of chitosan and anionic phosphate backbone of DNA. This binding protects the DNA from nuclease degradation and transfect DNA into different cell types. ${ }^{22,46}$ Here, the UV-visible, competitive fluorescence measurements and CD analysis have revealed the ability of CS to interact with DNA via intercalation with strong binding affinity. Noncovalent binders such as intercalating agents are known to induce toxicity in cancer cells by triggering apoptosis. In addition, some of these agents induce cytotoxicity via cell cycle arrest in rapidly dividing cells. To sum up, regarding specific antiproliferative activity of CS towards breast cancer cells, our results confirmed the potential of using CS as an anti-cancer agent compound.

\section{Conflicts of interest}

There are no conflicts to declare. 


\section{References}

1 S. Hati, S. Tripathy, P. K. Dutta, R. Agarwal, R. Srinivasan, A. Singh, S. Singh and S. Sen, Sci. Rep., 2016, 6, 32213.

2 R. E. Doherty, I. V. Sazanovich, L. K. McKenzie, A. S. Stasheuski, R. Coyle, E. Baggaley, S. Bottomley, J. A. Weinstein and H. E. Bryant, Sci. Rep., 2016, 6, 22668.

3 L. Gao, Y. Wang, Z. Xu, X. Li, J. Wu, S. Liu, P. Chu, Z. Sun, B. Sun and Y. Lin, Apoptosis, 2015, 20, 1636-1650.

4 K. Wang, C. Zhang, J. Bao, X. Jia, Y. Liang, X. Wang, M. Chen, H. Su, P. Li and J.-B. Wan, Sci. Rep., 2016, 6, 26064.

5 A. K. Mukherjee, A. J. Saviola, P. D. Burns and S. P. Mackessy, Apoptosis, 2015, 20, 1358-1372.

6 L.-H. Wu, P. Li, Q.-L. Zhao, J.-L. Piao, Y.-F. Jiao, M. Kadowaki and T. Kondo, Apoptosis, 2014, 19, 1654-1663.

7 M. R. Gill, S. N. Harun, S. Halder, R. A. Boghozian, K. Ramadan, H. Ahmad and K. A. Vallis, Sci. Rep., 2016, 6, 31973.

8 L. H. Hurley, Nat. Rev. Cancer, 2002, 2, 188-200.

9 S. Selvaraj, S. Krishnaswamy, V. Devashya, S. Sethuraman and U. M. Krishnan, RSC Adv., 2012, 2, 2797-2802.

10 H. Huang, P. Zhang, Y. Chen, K. Qiu, C. Jin, L.-N. Ji and H. Chao, Dalton Trans., 2016, 13135-13145.

11 M. A. Husain, S. U. Rehman, H. M. Ishqi, T. Sarwar and M. Tabish, RSC Adv., 2015, 5, 64335-64345.

12 M. Sirajuddin, S. Ali and A. Badshah, J. Photochem. Photobiol., B, 2013, 124, 1-19.

13 Y. Chen, K. Ma, T. Hu, B. Jiang, B. Xu, W. Tian, J. Z. Sun and W. Zhang, Nanoscale, 2015, 7, 8939-8945.

14 R. Manikandan, N. Chitrapriya, Y. J. Jang and P. Viswanathamurthi, RSC Adv., 2013, 3, 11647-11657.

15 X.-F. Zhang, R.-q. Sun, Y.-f. Jia, Q. Chen, R.-F. Tu, K.-k. Li, X.-D. Zhang, R.-L. Du and R.-h. Cao, Sci. Rep., 2016, 6, 33204.

16 G. Liu, S. Kuang, S. Wu, W. Jin and C. Sun, Sci. Rep., 2016, 6, 26722.

17 A. Zong, H. Cao and F. Wang, Carbohydr. Polym., 2012, 90, 1395-1410.

18 M. N. R. Kumar, React. Funct. Polym., 2000, 46, 1-27.

19 A. Rajalakshmi, N. Krithiga and A. Jayachitra, Middle East J. Sci. Res., 2013, 16, 1446-1451.

20 B. Santos-Carballal, L. Aaldering, M. Ritzefeld, S. Pereira, N. Sewald, B. Moerschbacher, M. Götte and F. Goycoolea, Sci. Rep., 2015, 5, 13567.

21 A. Anitha, S. Sowmya, P. S. Kumar, S. Deepthi, K. Chennazhi, H. Ehrlich, M. Tsurkan and R. Jayakumar, Prog. Polym. Sci., 2014, 39, 1644-1667.

22 Y. Wang, X. Zhang and G. Yang, RSC Adv., 2015, 5, 2959429600.

23 M. Dash, F. Chiellini, R. Ottenbrite and E. Chiellini, Prog. Polym. Sci., 2011, 36, 981-1014.
24 S. Hajji, I. Younes, M. Rinaudo, K. Jellouli and M. Nasri, Appl. Biochem. Biotechnol., 2015, 177, 18-35.

25 E. Szymańska and K. Winnicka, Mar. Drugs, 2015, 13, 18191846.

26 S. Chandra, N. Chakraborty, A. Dasgupta, J. Sarkar, K. Panda and K. Acharya, Sci. Rep., 2015, 5, 15195.

27 J. R. Gilbert and J. M. Vance, Current Protocols in Human genetics, 2001, p. 6.

28 L. M. Bravo-Anaya, J. A. Soltero and M. Rinaudo, Int. J. Biol. Macromol., 2016, 88, 345-353.

29 Z. Wang, H. Zhang, M. Shi, Y. Yu, H. Wang, W.-M. Cao, Y. Zhao and H. Zhang, Sci. Rep., 2016, 6, 32737.

30 M. Huang, E. Khor and L.-Y. Lim, Pharm. Res., 2004, 21, 344353.

31 C. A. Livasy, G. Karaca, R. Nanda, M. S. Tretiakova, O. I. Olopade, D. T. Moore and C. M. Perou, Mod. Pathol., 2006, 19, 264.

32 K. Palanivel, V. Kanimozhi, B. Kadalmani and M. A. Akbarsha, J. Cell. Biochem., 2014, 115, 2022-2032.

33 N. Shahabadi and N. H. Moghadam, Spectrochim. Acta, Part $A, 2012,96,723-728$.

34 X. Zhou, G. Zhang and J. Pan, Int. J. Biol. Macromol., 2015, 74, 185-194.

35 S. Agarwal, D. K. Jangir and R. Mehrotra, J. Photochem. Photobiol., B, 2013, 120, 177-182.

36 S. Nafisi, A. A. Saboury, N. Keramat, J.-F. Neault and H.-A. Tajmir-Riahi, J. Mol. Struct., 2007, 827, 35-43.

37 R. Bera, B. K. Sahoo, K. S. Ghosh and S. Dasgupta, Int. J. Biol. Macromol., 2008, 42, 14-21.

38 S. Bhattacharya, G. Mandal and T. Ganguly, J. Photochem. Photobiol., B, 2010, 101, 89-96.

39 K. S. Ghosh, B. K. Sahoo, D. Jana and S. Dasgupta, J. Inorg. Biochem., 2008, 102, 1711-1718.

40 S. Dogra, P. Awasthi, M. Nair and R. Barthwal, J. Photochem. Photobiol., B, 2013, 123, 48-54.

41 L. Gibot, S. Chabaud, S. Bouhout, S. Bolduc, F. A. Auger and V. J. Moulin, Int. J. Biol. Macromol., 2015, 72, 370-379.

42 N. Jaiswal, C. K. Maurya, D. Arha, D. R. Avisetti, A. Prathapan, P. S. Raj, K. G. Raghu, S. V. Kalivendi and A. K. Tamrakar, Apoptosis, 2015, 20, 930-947.

43 E. J. Lim, J. Heo and Y.-H. Kim, Apoptosis, 2015, 20, 10871098.

44 P. Xu, X. Cai, W. Zhang, Y. Li, P. Qiu, D. Lu and X. He, Apoptosis, 2016, 21, 1125-1143.

45 K. Bishayee, S. Ghosh, A. Mukherjee, R. Sadhukhan, J. Mondal and A. Khuda-Bukhsh, Cell Proliferation, 2013, 46, 153-163.

46 D. Agudelo, L. Kreplak and H. Tajmir-Riahi, Carbohydr. Polym., 2016, 137, 207-213. 